\title{
EFFECT OF CROPPING SYSTEMS IN NO-TILL FARMING ON THE QUALITY OF A BRAZILIAN OXISOL ${ }^{(1)}$
}

\author{
Getulio de Freitas Seben Junior ${ }^{(2)}$, José Eduardo Corá( ${ }^{(3)} \& \operatorname{Rattan}_{\text {Lal }}^{(4)}$
}

\begin{abstract}
SUMMARY
The no-till system with complex cropping sequences may improve the structural quality and carbon (C) sequestration in soils of the tropics. Thus, the objective of this study was to evaluate the effects of cropping sequences after eight years under the no-till system on the physical properties and $\mathrm{C}$ sequestration in an Oxisol in the municipality of Jaboticabal, Sao Paulo, Brazil. A randomized split-block design with three replications was used. The treatments were combinations of three summer cropping sequences - corn/corn (Zea mays L.) (CC), soybean/soybean (Glycine max L. Merryll) (SS), and soybean-corn (SC); and seven winter crops - corn, sunflower (Helianthus annuus L.), oilseed radish (Raphanus sativus L.), pearl millet (Pennisetum americanum (L.) Leeke), pigeon pea (Cajanus cajan (L.) Millsp), grain sorghum (Sorghum bicolor (L.) Moench), and sunn hemp (Crotalaria juncea L.). Soil samples were taken at the 0-10 cm depth after eight years of experimentation. Soil under SC and CC had higher mean weight diameter (3.63 and $3.55 \mathrm{~mm}$, respectively) and geometric mean diameter (3.55 and $2.92 \mathrm{~mm})$ of the aggregates compared to soil under SS (3.18 and $2.46 \mathrm{~mm})$. The $\mathrm{CC}$ resulted in the highest soil organic $\mathrm{C}$ content $\left(17.07 \mathrm{~g} \mathrm{~kg}^{-1}\right)$, soil $\mathrm{C}$ stock $\left(15.70 \mathrm{Mg} \mathrm{ha}^{-1}\right)$, and rate of C sequestration ( $0.70 \mathrm{Mg} \mathrm{ha}^{-1} \mathrm{yr}^{-1}$ ) among the summer crops. Among the winter crops, soil under pigeon pea had the highest total porosity $\left(0.50 \mathrm{~m}^{3} \mathrm{~m}^{-3}\right)$, and that under sunn hemp had the highest water stable aggregates (93.74\%). In addition, sunn hemp did not differ from grain sorghum and contained the highest soil organic $\mathrm{C}$ content (16.82 $\left.\mathrm{g} \mathrm{kg}^{-1}\right)$ and also had the highest rate of $\mathrm{C}$ sequestration $\left(0.67 \mathrm{Mg} \mathrm{ha}^{-1} \mathrm{yr}^{-1}\right)$. The soil resistance to penetration was the lower limit of the least limiting water range, while the upper limit was air-filled porosity for soil bulk densities higher than $1.39 \mathrm{~kg} \mathrm{dm}^{-3}$ for all cropping sequences. Within the SC sequence, soil under corn and pigeon pea increased least limiting water range by formation of biopores because soil resistance to penetration decreased with the increase in soil bulk density.

Index terms: Cerrado, crop rotation, winter crops, soil aggregates, least limiting water range, bulk density.

(1) Excerpt from the Doctoral Thesis of the first author. Received on July 17, 2013 and approved on April 25, 2014.

(2) Adjunct Professor, Universidade do Estado de Mato Grosso - UNEMAT, Campus of Alta Floresta. Av. Perimetral Rogério Silva, s/n, Jardim Flamboyant. CEP 78580-000 Alta Floresta (MT). E-mail: getulioseben@unemat.br

(3) Associate Professor, Soil Science Department, Sao Paulo State University - UNESP, Campus of Jaboticabal. Via de Acesso Prof. Paulo Donato Castellane, s/n. CEP 14884-900 Jaboticabal (SP). CNPq Researcher. E-mail: cora@fcav.unesp.br

(4) Professor Emeritus of The Ohio State University, School of Environment and Natural Resources. 2021 Coffey Rd., Columbus,
\end{abstract} OH 43210, USA. E-mail: lal.1@osu.edu 


\title{
RESUMO: SEQUÊNCIAS DE CULTURAS EM SISTEMA DE SEMEADURA DIRETA SOBRE A QUALIDADE FÍSICA DE UM LATOSSOLO
}

\begin{abstract}
O cultivo intensivo de sequências de culturas em sistema de semeadura direta proporciona o incremento de carbono (C) e a melhoria da qualidade estrutural do solo. Portanto, o objetivo deste estudo foi avaliar os efeitos de sequências de culturas em sistema de semeadura direta sobre o acúmulo de Ce as propriedades físicas do solo em um Latossolo em Jaboticabal, SP, Brasil. O delineamento utilizado foi em faixas, com três repetições. Os tratamentos foram constituídos da combinação de três culturas de verão: milho/milho (Zea mays L.)(MM), soja / soja (Glycine max L. Merryll) (SS) e soja/milho (SM); e sete culturas de inverno: milho, girassol (Helianthus annuus L.), nabo-forrageiro (Raphanus sativus L.), milheto (Pennisetum americanum (L.) Leeke), feijão-guandu (Cajanus cajan (L.) Mill sp.), sorgo (Sorghum bicolor (L.) Moench), e crotalária (Crotalaria juncea $L$.). O solo foi amostrado na profundidade de 0-0.10 m, após oito anos de experimentação. O solo sob SMe MMapresentou o maior diâmetro médio ponderado $(3,63$ e $3,55 \mathrm{~mm})$ e diâmetro médio geométrico $(3.55$ e $2.92 \mathrm{~mm})$ dos agregados, em comparação ao solo sob $S S(3,18$ e 2,46 mm). O MM proporcionou o maior teor de $C\left(17,07 \mathrm{~g} \mathrm{~kg}^{-1}\right)$, o maior estoque de $C\left(15,70 \mathrm{Mg} \mathrm{ha}^{-1}\right)$ e a maior taxa de sequestro de C (0.70 $\mathrm{Mg} \mathrm{ha}^{-1}$ ano $\left.^{-1}\right)$, entre as culturas de verão. Entre as culturas de inverno, o feijãoguandu proporcionou a maior porosidade total $\left(0,50 \mathrm{~m}^{3} \mathrm{~m}^{-3}\right)$, enquanto a crotalária propiciou

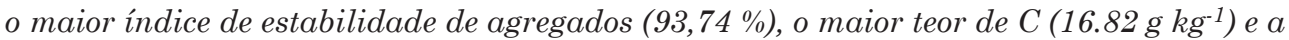
maior taxa de sequestro de $C\left(0,67 \mathrm{Mg} \mathrm{ha}^{-1}\right.$ ano-1 $)$. A resistência do solo à penetração representou o limite inferior do intervalo hídrico ótimo, enquanto o limite superior foi representado pela porosidade de aeração para valores de densidade do solo maiores que $1,39 \mathrm{~kg} \mathrm{dm}^{-3}$, determinados em todas as sequências de culturas. O milho e o feijão-guandu cultivados no SM proporcionaram o aumento do intervalo hídrico ótimo pela formação de bioporos, pois a resistência do solo à penetração diminuiu com o incremento da densidade do solo.
\end{abstract}

Termos de indexação: Cerrado, rotação de culturas, culturas de inverno, agregados, intervalo hídrico ótimo, densidade do solo.

\section{INTRODUCTION}

Oxisols are highly weathered and have a strong microstructure due to the presence of $\mathrm{Fe}$ - and $\mathrm{Al}$-oxides and hydroxides (Six et al., 2002). However, soil structure is prone to degradation in agricultural areas due to intense soil disturbance, erosion process by rainfall, high temperature, and low input of biomass carbon (C). A no-till system is widely recommended to minimize these adverse effects and improve soil quality. The no-till system improves structural properties and can enhance $\mathrm{C}$ sequestration in soils of tropical regions at a rate of $0.35 \mathrm{Mg} \mathrm{ha}^{-1} \mathrm{yr}^{-1} \mathrm{C}$ in the $0-0.20 \mathrm{~m}$ depth (Bayer et al., 2006), and 0.43 $\mathrm{Mg} \mathrm{ha}^{-1} \mathrm{yr}^{-1} \mathrm{C}$ in the 0-0.10 m depth (Six et al., 2002), contributing to mitigation of global warming (Bayer et al., 2006). However, the intensity of no-till effects on soil quality depends on specific cropping sequences.

However, establishment of cropping sequences in regions of the Cerrado (tropical savanna) biome, especially of winter crops, is limited by a relatively dry season from April to September. Thus, winter crops must have a deep and vigorous root system (Marcelo et al., 2009) and exhibit fast establishment to produce the maximum biomass by late autumn, after which the rains cease (Bayer et al., 2006).

The magnitude of general above-ground biomass is critical for reducing slaking and erosion of the soil surface. Additionally, the root system is important for increasing soil aggregation and long-term $\mathrm{C}$ sequestration in the soil (Six et al., 2002). Martins et al. (2012) verified increases in aggregation of an Oxisol under no-till cropping sequences involving pearl millet and grain sorghum (Poaceae species), but, in this case, a smaller quantity of roots as compared to oilseed radish (legume) was observed. Thus, these authors concluded that aggregation is indirectly affected by the input of plant pentose through the input of aboveground biomass. In tropical regions, grasses enhance aggregation compared to legumes because of the favorable quantity and distribution of the roots in the soil, periodic renewal, uniform distribution of exudates, and lateral soil compaction during development and water uptake (Silva \& Mielniczuk, 1997; Six et al., 2002; Martins et al., 2009; 2012).

Establishment of winter crops increases biopores in compacted layers by deep root systems (Williams \& Weil, 2004) and reduces critical bulk density in soil under no-till. Such favorable effects may even be observed in the first years because of the absence of soil disturbance and reduction in machine traffic (Tormena et al., 1998). A decrease in critical bulk density by root growth depends on the soil texture, mineralogy, particle shape, and soil organic matter content, which affect water and air movement and soil resistance to penetration (Reichert et al., 2009).

Soil structural quality may be assessed by determining a balance in fluid (air vs water) transmission, water storage, nutrients in the soil 
solution, and air-filled porosity (Topp et al., 1997). A favorable level of these attributes is important for improving crop growth, while reducing the risk of accelerated erosion and promoting root growth (Reynolds et al., 2002). The range of soil properties which improve plant growth depends on strong interaction among soil resistance to penetration, airfilled porosity, and available water capacity, which is obtained from the difference between field capacity and the permanent wilting point (Tormena et al., 2007). What is known as the least limiting water range (Letey, 1985; Silva et al., 1994; Tormena et al., 1998) is equivalent to the range of water content in soil in which plants may grow without being constrained by soil properties which restrict physiological processes (Reynolds et al., 2002). Thus, the least limiting water range is an important indicator of soil structural quality in relation to crop yield (Silva et al., 1994).

Therefore, it is important to evaluate the effects of plants on soil structural properties within specific cropping sequences, and to understand which and how soil attributes may be affected by specific crops. Thus, the present study was carried out to test the hypothesis that cropping sequences affect soil structural properties. The objective of the study was to evaluate the effects of cropping sequences under no-till on soil structure and soil organic $\mathrm{C}$ sequestration.

\section{MATERIALS AND METHODS}

The field experiment was set up in 2002 in the municipality of Jaboticabal, Sao Paulo, Brazil ( $21^{\circ} 15^{\prime} 22^{\prime \prime} \mathrm{S}, 48^{\circ} 18^{\prime} 58^{\prime \prime} \mathrm{W}, 550 \mathrm{~m}$ above sea level). The climate at the experimental site is classified as Aw according to the Köppen classification (dry and warm winter with a temperature greater than $18^{\circ} \mathrm{C}$ ), with mean annual temperature of $22{ }^{\circ} \mathrm{C}$, relative humidity of $70 \%$, and mean annual rainfall of $1,425 \mathrm{~mm}$. Rainfall is greater from October to March, with a relatively dry season from April to September. Details of some meteorological characteristics of the experimental site are shown in figure 1.

The soil of the experimental site is a Rhodic Eutrudox (Oxisol), according to USDA Soil Taxonomy (Soil Survey Staff, 2010). Particle size distribution in the $0-0.10 \mathrm{~m}$ layer consists of $556 \mathrm{~g} \mathrm{~kg}^{-1}$ of clay, 63 $\mathrm{g} \mathrm{kg}^{-1}$ of silt, and $381 \mathrm{~g} \mathrm{~kg}^{-1}$ of sand. Other mineralogical properties are detailed by Martins et al. (2009). The site history, soil chemical properties, lime applications, row spacing, and final plant populations of this experiment have been provided by Marcelo et al. (2009).

The experiment was laid out according to a splitblock design with three replications (blocks). Each experimental block was composed of 21 plots, which consisted of three summer cropping sequences combined with seven winter crops in a no-till system.

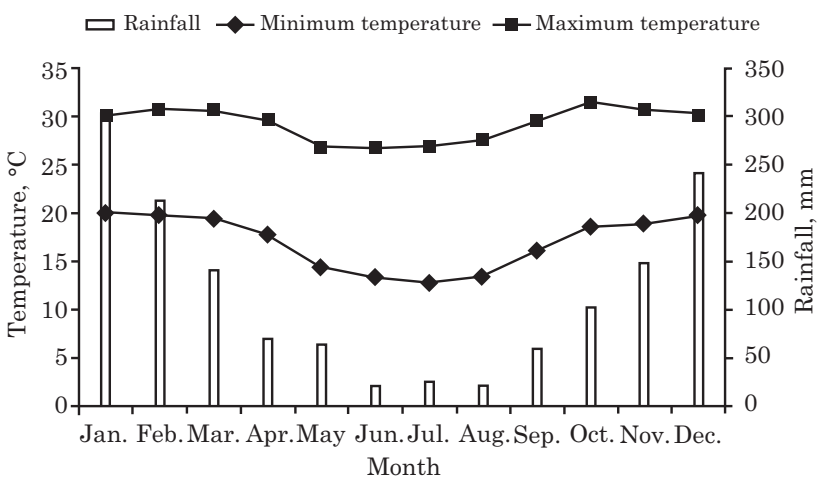

Figure 1. Long-term monthly average maximum and minimum temperatures and rainfall at the experimental site (1971-2010).

Each plot was $40 \mathrm{~m}$ long and $15 \mathrm{~m}$ wide. The summer cropping sequences were the following: corn/corn (Zea mays L.), soybean/soybean (Glycine max L. Merrill), and soybean/corn, with intercropping every other year. Winter crops consisted of corn, sunflower (Helianthus annuus L.), oilseed radish (Raphanus sativus L.), pearl millet (Pennisetum americanum (L.) Leeke), pigeon pea (Cajanus cajan (L.) Millsp), grain sorghum (Sorghum bicolor (L.) Moench), and sunn hemp (Crotalaria juncea L.), sown in February/March. The same winter crop was grown in the same plot during each growing season.

Soil samples were obtained in October 2010 during the eighth year of the experiment (2009/2010) after harvesting the winter crops and before sowing the summer crops. A total of 20 subsamples were obtained from the 0-0.10 $\mathrm{m}$ depth at random within each plot using a straight spade and they were combined. In addition, at the same depth, 28 undisturbed core samples were also obtained from each plot. Soil samples were placed within plastic bags to preserve structure and the moisture content during transport to the laboratory.

The composite disturbed samples were broken up manually at field moisture content and divided into three portions. The first portion was sieved to obtain soil aggregates from 6.3 to $4.0 \mathrm{~mm}$, the second was sieved to obtain aggregates from 2.0 to $1.0 \mathrm{~mm}$, and the third was air dried for $48 \mathrm{~h}$ and ground to pass through a $2.00 \mathrm{~mm}$ sieve.

The air dried soil aggregates of the 4.0 to $6.3 \mathrm{~mm}$ size fraction were used to determine the mean weight diameter and geometric mean diameter of the aggregates (Nimmo \& Perkins, 2002). Three replicates of aggregates of $40 \mathrm{~g}$ and one of $10 \mathrm{~g}$ were weighed. The $10 \mathrm{~g}$ sample was oven dried at $105^{\circ} \mathrm{C}$ for $24 \mathrm{~h}$ to determine the soil moisture content. The other three samples were used for wet sieving by using a nest of five sieves: 4.00, 2.00, 1.00, 0.50, and $0.25 \mathrm{~mm}$. After the aggregates in the top sieve $(4.00 \mathrm{~mm})$ were wetted under capillarity, the nest of sieve was oscillated under water by using the Yoder device (Yoder, 1936). Samples 
were subjected to wet sieving for 15 min at 31 cycles $\mathrm{min}^{-1}$ and a $35-\mathrm{mm}$ amplitude.

Soil aggregates of 1.0-2.0 mm diameter were used to determine the water stable aggregates (Yoder, 1936). Four replicates of $10 \mathrm{~g}$ of $1.0-2.0 \mathrm{~mm}$ soil aggregates were weighed, and one of the four was used to determine soil moisture content by oven drying at $105^{\circ} \mathrm{C}$ for $24 \mathrm{~h}$. The other three replicates were used to determine water stable aggregates by using a sieve of $0.25 \mathrm{~mm}$ mesh size. After the aggregates were wetted by capillarity, the sieve was oscillated under water for 3 min at 35 cycles min $^{-1}$, with an oscillation amplitude of $13 \mathrm{~mm}$ (Yoder, 1936).

In both methods of wet sieving, soil retained in each sieve after oscillation under water was transferred to weighed aluminum capsules and oven dried at $105{ }^{\circ} \mathrm{C}$ for $24 \mathrm{~h}$. Aggregates retained in each sieve were used to determine its sand content for coarse and fine sand fractions (Kemper \& Rosenau, 1986). To quantify the sand fraction, the oven-dried soil in the aluminum capsules was dispersed by adding 100 $\mathrm{mL}$ of $0.1 \mathrm{~mol} \mathrm{~L}^{-1} \mathrm{NaOH}$ and shaking at 60 cycles $\min ^{-1}$ for $16 \mathrm{~h}$. The suspension was passed through the same nest of sieves that retained aggregates during the wet sieving procedure $(0.5$ and $0.25 \mathrm{~mm})$. The sand fractions retained in the sieves were collected into the corresponding aluminum capsules, placed in an oven at $105^{\circ} \mathrm{C}$ for $24 \mathrm{~h}$, and weighed. Using the data on the weight of the aggregates retained in each sieve, moisture content, and sand fraction; the mean weight diameter, geometric mean diameter, and water stable aggregates were computed (Kemper \& Rosenau, 1986).

$$
\text { Mean weight diameter }=\sum_{i=1}^{6}(x i-w i)
$$

where $w i$ is the weight of aggregates in the $i^{\text {th }}$ size class with a mean diameter $x i$.

Geometric mean diameter $=\exp \left[\sum_{i=1}^{n}\right.$ wi $\left.\log \overline{x i} / \sum_{i=1}^{n} w i\right]$ where $w i$ is the weight of aggregates in a size class with an average diameter $x i$, and $\sum_{i=1}^{n} w i$ is the total weight of the sample.

$$
\text { Water stable aggregates }=\left(\frac{w i-x i}{w i}\right) \times 100
$$

where $w i$ is the weight of aggregates and $x i$ is the weight of aggregates retained in the sieve of $0.025 \mathrm{~m}$.

Soil organic carbon (SOC) was determined by dry combustion at $900^{\circ} \mathrm{C}$ (Nelson \& Sommers, 1982) using $300 \mathrm{mg}$ of ground samples $(<105 \mu \mathrm{m})$. Soil organic carbon was transformed to the equivalent soil layer (Bayer et al., 2000), which considers thickness and density of the soil. The SOC stock was also calculated by equivalent mass basis (Ellert \& Bettany, 1995), which considers a standard treatment as a baseline to calculate the SOC stock for other treatments. The SOC content under a native forest $\left(30.16 \mathrm{~g} \mathrm{~kg}^{-1}\right)$, adjacent to the study site, was used as a baseline to assess the impact of cropping sequences. Considering the soil organic matter content of $19.0 \mathrm{~g} \mathrm{~kg}^{-1}$ in the soil prior to implementation of this experiment in 2002 , the rate of SOC sequestration was computed (final initial/time in years) for the cropping sequence treatments.

Yield of crop residue was evaluated at two different times. The first evaluation involved only quantification of the above-ground biomass and it occurred when the crops (oilseed radish, pearl millet, pigeon pea, and sunn hemp) were at the full bloom and when grain crops (corn, sunflower, grain sorghum, and soybean) were at the harvest stage. The above ground biomass was assessed by harvesting a onemeter-long row at three randomly selected locations in each plot, and the harvest was combined. The second evaluation was done to quantify the crop residue left on the soil surface after they were cropped (cover crops) or harvested (grain crops). All residues remaining on soil surface contained within a quadrat of $0.25 \mathrm{~m}^{2}$ were collected at five random locations within each plot, thus the harvest was composed and weighed (Stott et al., 1990). For both methods, a sub-sample was oven-dried $\left(65^{\circ} \mathrm{C}\right)$ to determine the dry matter.

The least limiting water range was determined according to the method of Silva et al. (1994). Critical values for plant growth were obtained from the literature, i.e., field capacity at $-0.01 \mathrm{MPa}$ (Reichardt, 1988), permanent wilting point at -1.5 $\mathrm{MPa}$ (Savage et al., 1996), air-filled porosity at $10 \%$ (Grable \& Siemer, 1968), and soil resistance to penetration at 3.5 MPa, considering bioporosity in soil under the notill system (Ehlers et al., 1983; Tormena et al., 2007; Blainski et al., 2012).

The least limiting water range was determined as the average of three replications for each matric potential. Thus, seven undisturbed soil cores were collected from each plot (six cores of $0.05 \mathrm{~m}$ height $\times$ $0.05 \mathrm{~m}$ diameter and one core of $0.025 \mathrm{~m}$ height $\times$ $0.05 \mathrm{~m}$ diameter). These cores were separated into seven groups with 63 cores and were wetted by capillarity. Each group was subjected to water suctions of 60 and $100 \mathrm{hPa}$ on a Tension Table (Romano et al., 2002), and 330, 600, 1000, 3000, and $15000 \mathrm{hPa}$ on a series of Pressure Plate Extractors (Dane \& Hopmans, 2002). The group with the smallest cores $(0.025 \times 0.05 \mathrm{~m})$ were used to measure water retention at the suction of $15000 \mathrm{hPa}$ because of the long time required to reach equilibrium. Resistance to penetration was evaluated in each core at every matric potential using a penetrometer equipped with a linear actuator and load cell of $20 \mathrm{~kg}$, operated at a constant speed of $1.76 \mathrm{~mm} \mathrm{~s}^{-1}$, and coupled to a computer for data acquisition (Figueiredo et al., 2011). The penetrometer cone had a $30^{\circ}$ angle and a base diameter of $3.91 \mathrm{~mm}$. These data were used to calculate 
the least limiting water range (Silva et al., 1994). The empirical parameters used to adjust the equations to obtain the least limiting water range and the critical bulk density were obtained using a simplified algorithm developed in Excel ${ }^{\circledR}$ software by Leão \& Silva (2004). Additionally, the total porosity, micro-, and macroporosity were determined by the method proposed by Flint \& Flint (2002).

Water dispersed clay was determined by the pipette method (Gee \& Bauder, 1986). Briefly described, $10 \mathrm{~g}$ of dry soil $(<2.0 \mathrm{~mm})$ was put into a bottle containing $200 \mathrm{~cm}^{3}$ of water and shaken for $16 \mathrm{~h}$ in a Wiegner rotary shaker at 60 cycles $\mathrm{min}^{-1}$. Clay content was also obtained by the pipette method (Gee \& Bauder, 1986) using $10 \mathrm{~mL}$ of $\mathrm{NaOH}$ as a dispersant solution. The degree of flocculation was obtained by:

$$
\text { Degree of flocculation }=\frac{\text { clay content }- \text { water dispersed clay }}{\text { clay content }}
$$

The data were subjected to analysis of variance according to a split-block design with three replications (blocks), except for the least limiting water range. Whenever the F-test was significant $(p<0.05)$, the means were compared by the Tukey test $(\alpha<0.05)$.

\section{RESULTS AND DISCUSSION}

A higher amount of above-ground biomass of the winter crops was measured in the soybean/soybean and soybean/corn sequences, as summer crops, when compared to those observed in the corn/corn sequence (Table 1). As soybean is a legume, the $\mathrm{N}$ fixed by it may be used by the following winter crop to produce the above-ground biomass. Soybean $\mathrm{N}$ fixation may range from 109 to $250 \mathrm{~kg} \mathrm{ha}^{-1} \mathrm{yr}^{-1} \mathrm{~N}$, where 70 to $85 \%$ is fixed in the plant residues (Hungria et al., 2001). In another experiment conducted at the same site in the 2007/2008 and 2008/2009 growing seasons, Marcelo et al. (2012) observed that the biomass of cereals such as pearl millet and grain sorghum increased by 56 and $69 \%$ when grown after soybean than after corn/corn in the summer. This high biomass yield was attributed to high availability of soil $\mathrm{N}$ introduced by biological fixation and the high potential of these cereal crops with an adequate supply of N (Marcelo et al., 2012). In a study to assess N uptake capacity and its effect on the biomass yield of corn in response to the addition of sunn hemp and pearl millet residues in an Oxisol, Silva et al. (2009) observed that corn biomass increased with the application of sunn hemp residues. Legume crop residues have a low $\mathrm{C} / \mathrm{N}$ ratio and a high rate of mineralization, thereby benefiting the following crop through a high and regular supply of $\mathrm{N}$ (Silva et al., 2009). An increase in biomass yield through the use of legume residues may enhance SOC content in the soil and improve the grain yield of cereal crops (Amado et al., 2001).
Among the winter crops, pigeon pea and pearl millet produced higher above-ground biomass than corn, sunflower, oilseed radish, and sunn hemp (Table 1). This trend may be due to the drought and cold tolerance of these species in regions with a dry winter. Pearl millet is used as a winter crop in dry tropical climates because of its fast growth and high biomass yield (Pacheco et al., 2011). Pigeon pea is also a suitable species for producing a high biomass yield with a low rate of decomposition because of a lower polysaccharide and a higher aromatic compound content. Thus, pigeon pea residues have higher aromaticity and hydrophobicity (Carvalho et al., 2009). Marcelo et al. (2012) also observed that pearl millet produced the highest above-ground biomass among all winter crops in an atypical wet winter (2007/2008) with $45 \%$ more rain than the long-term average (1971-2000), and in a typical dry winter (2008/2009). Further, the biomass yields of pigeon pea and sunn hemp did not differ from that of pearl millet following the corn/corn sequence as a summer crop (Marcelo et al., 2012). These trends were attributed to the adaptability of these winter crops to the Cerrado region of Brazil.

There were no differences in crop residues on the soil surface among summer crops (Table 1). Nonetheless, among winter crops, pigeon pea had the highest quantity of residue on the soil surface. Plots under pigeon pea also had the highest quantity of above-ground biomass contributing to residues on the soil surface. Alvarenga et al. (1995) also reported that pigeon pea produced a higher quantity of residues than sunn hemp, cowpea (Vigna unguiculata), feijão-bravodo-ceará (Canavalia brasiliense), jackbean (Canavalia ensiformis), lab-lab (Dolichos lab lab), and mucunapreta (Stizolobium aterrimum) in an Ultisol. The higher residue from pigeon peas was partly attributed to its greater root length and diameter with high penetration potential in the subsoil, which enhances water uptake from deeper soil layers (Alvarenga et. al., 1995).

Both SOC content and SOC stock were significantly influenced by the summer cropping sequences (Table 1). Soil under corn/corn had higher SOC content and stock than that under soybean/corn, which was cultivated with soybean in the last year. Furthermore, the corn root system is more relevant for improving the SOC stock than the addition of above-ground residues to the soil surface because the $\mathrm{C}$ in the root biomass is better stabilized into aggregates in the soil profile (Santos et al., 2011). Corn residues on the soil surface, with a higher $\mathrm{C} / \mathrm{N}$ ratio compared to that of the soybean, are more persistent on the soil surface (Martins et al., 2012). Residues on the soil surface protect soil aggregates against the degradation of SOC by microorganisms (Sollins et al., 1996). This hypothesis was also confirmed for the same site by Martins et al. (2012), who observed that corn as a summer crop (corn/corn and soybean/corn) increased mean weight diameter, compared to soybean/soybean, because its residues are rich in pentoses, mainly 
Table 1. Above-ground biomass (AGB) and residues on the soil surface (RSS) produced by winter crops, and soil organic carbon content (SOCc), soil organic carbon stock (SOCs), water-dispersed clay (WDC), and degree of flocculation (DF) determined at the 0-0,10 $\mathrm{m}$ depth of an Oxisol under summer and winter crop sequences in a no-till system

\begin{tabular}{|c|c|c|c|c|c|c|}
\hline & AGB & RSS & SOCc & SOCs & WDC & DF \\
\hline & -1 & 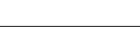 & $\mathrm{g} \mathrm{kg}^{-1}$ & $\mathrm{Mg} \mathrm{ha}^{-1}$ & $\mathrm{~g} \mathrm{~kg}^{-1}$ & $\%$ \\
\hline \multicolumn{7}{|l|}{ Summer crop (S) } \\
\hline Soybean/corn & $4.89 \mathrm{a}$ & 5.07 & $14.53 \mathrm{~b}$ & $13.37 \mathrm{~b}$ & $378 \mathrm{ab}$ & $36 \mathrm{a}$ \\
\hline Corn/corn & $3.03 \mathrm{~b}$ & 4.86 & $17.07 \mathrm{a}$ & $15.70 \mathrm{a}$ & $368 \mathrm{~b}$ & $32 \mathrm{ab}$ \\
\hline Soybean/soybean & $4.50 \mathrm{a}$ & 5.20 & $16.38 \mathrm{ab}$ & $15.07 \mathrm{ab}$ & 383 a & $30 \mathrm{~b}$ \\
\hline F test & $20.97^{*}$ & $0.36^{\mathrm{ns}}$ & $3.68^{*}$ & $3.67^{*}$ & $7.9^{*}$ & $7.1^{*}$ \\
\hline CV (\%) & 23.8 & 32.4 & 13.6 & 19.6 & 3.4 & 17.9 \\
\hline \multicolumn{7}{|l|}{ Winter crop (W) } \\
\hline Corn & $2.51 \mathrm{c}$ & $5.54 \mathrm{ab}$ & $16.18 \mathrm{ab}$ & 14.88 & 357 & 32 \\
\hline Sunflower & $2.60 \mathrm{c}$ & $3.81 \mathrm{c}$ & $15.34 \mathrm{~b}$ & 14.11 & 356 & 33 \\
\hline Oilseed radish & $3.22 \mathrm{c}$ & $4.35 \mathrm{~b}$ & $15.72 \mathrm{ab}$ & 14.47 & 378 & 31 \\
\hline Pearl millet & $4.88 \mathrm{ab}$ & $5.18 \mathrm{abc}$ & $15.47 \mathrm{ab}$ & 14.23 & 371 & 32 \\
\hline Pigeon pea & $5.24 \mathrm{a}$ & $6.35 \mathrm{a}$ & $15.60 \mathrm{ab}$ & 14.35 & 370 & 34 \\
\hline Grain sorghum & $3.96 \mathrm{bc}$ & $5.14 \mathrm{abc}$ & $16.82 \mathrm{a}$ & 15.47 & 402 & 32 \\
\hline Sunn hemp & $2.58 \mathrm{c}$ & 3.57 & 16.82 & 15.47 & 397 & 35 \\
\hline $\mathrm{F}$ test & $18.56^{*}$ & $9.12^{*}$ & $1.59^{*}$ & $1.58^{\mathrm{ns}}$ & $1.5^{\mathrm{ns}}$ & $1.2^{\mathrm{ns}}$ \\
\hline CV (\%) & 36.4 & 36.6 & 9.1 & 9.3 & 11.9 & 11.0 \\
\hline \multicolumn{7}{|l|}{ Interaction $\mathrm{S} \times \mathrm{W}$} \\
\hline $\mathrm{F}$ test & $5.31^{\mathrm{ns}}$ & $1.46^{\mathrm{ns}}$ & $1.59^{\mathrm{ns}}$ & $1.61^{\mathrm{ns}}$ & $1.0^{\mathrm{ns}}$ & $1.1^{\mathrm{ns}}$ \\
\hline CV (\%) & 20.5 & 32.0 & 9.8 & 9.7 & 4.3 & 11.3 \\
\hline
\end{tabular}

Values followed by the same lowercase letters in the columns are not significantly different by the Tukey test $(\mathrm{p}<0.05) .{ }^{*} \mathrm{p}<0.05$, ${ }^{\text {ns }}$ not significant.

derived from the above-ground biomass. However, a low amount of residues on the soil surface decreased SOC content by increasing temperature amplitude, which accentuates oxidation (Eltz \& Rovedder, 2005).

The SOC stock did not differ among the winter crops (Table 1). Nonetheless, the SOC content was higher in soil under grain sorghum and sunn hemp than soil under sunflower. Grain sorghum and sunn hemp have deep and prolific root systems with a high capacity of development in the soil profile, which increases SOC in the subsoil (Marcelo et al., 2009; Calonego \& Rosolem, 2010). Marcelo et al. (2009) also observed that grain sorghum, sunn hemp, pearl millet, and oilseed radish increased SOC content in the 0$0.30 \mathrm{~m}$ depth compared to SOC content under corn, sunflower, and pigeon pea.

Among the summer crop sequences, corn/corn led to soil with a higher rate of $\mathrm{C}$ sequestration than soybean/corn (Figure 2). In general, corn/corn had more residues and more biomass- $\mathrm{C}$ input than soybean/corn (West \& Post, 2002). Among the winter crops, grain sorghum and sunn hemp led to higher rates of SOC sequestration than sunflower (Figure 2). In addition, the $0-0.10 \mathrm{~m}$ soil layer under all cropping sequences had a higher rate of SOC sequestration than the average rate of $0.43 \mathrm{Mg} \mathrm{ha}^{-1} \mathrm{y}^{-1}$ $\mathrm{C}$ for Brazilian tropical soils under no-till management
(Six et al., 2002). A high rate of SOC sequestration may be attributed to the winter crop established before the dry season.

The water dispersed clay and degree of flocculation were significantly affected only by the summer crops (Table 1). Relatively higher water dispersed clay was observed in soil under soybean/soybean compared to that under corn/corn and a lower degree of flocculation than that under soybean/corn. An increase in dispersed clay and a reduction in the degree of flocculation in the soil under soybean/soybean indicated higher erodibility and the formation of compacted layers. In contrast, lower water dispersed clay under corn/corn may be associated with low soil aggregation because of low SOC content. The SOC content may be strongly correlated with water dispersed clay, indicating the importance of SOC on clay stabilization (Beutler et al., 2001).

Growing corn as a summer crop (continuously or in rotation) increased the mean weight diameter and the geometric mean diameter of the soil compared to soybean (Table 2). These results may be attributed to the capacity of the corn roots in approaching soil mineral particles and cementing them by the input of the SOC. The quantity, configuration, and distribution of corn roots in the soil surface layer strongly influence aggregation since about $83 \%$ of 


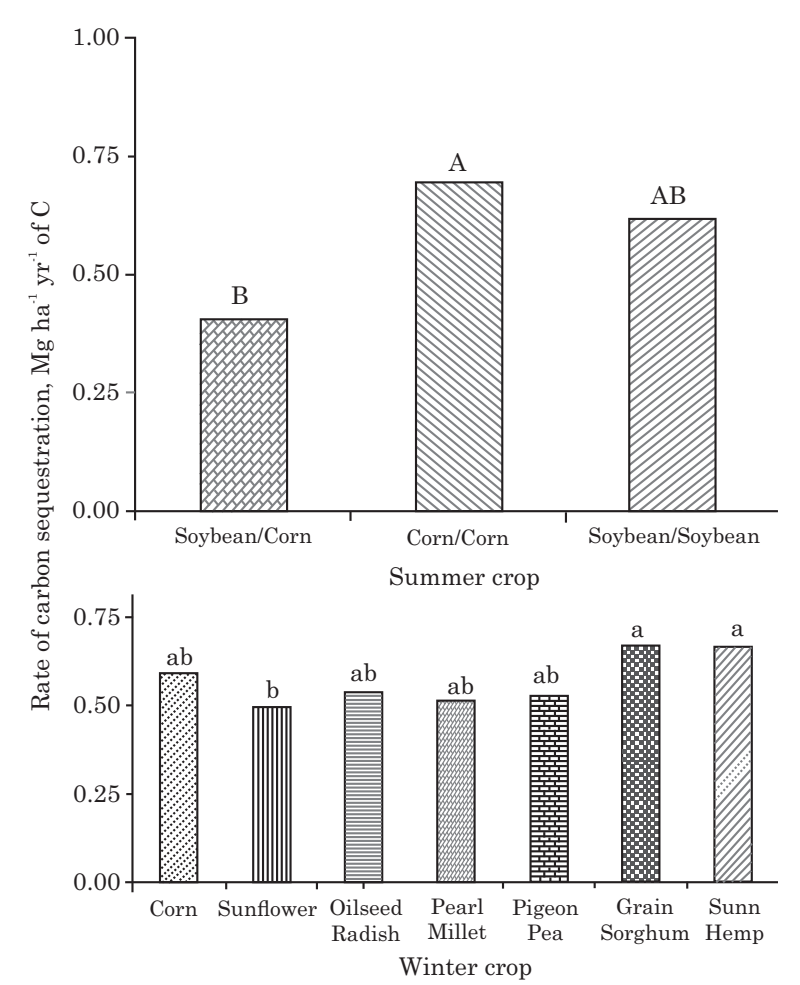

Figure 2. Rate of carbon sequestration in an Oxisol under summer and winter cropping sequences in a notill system. Same letters above the bars are not significantly different by theTukey test $(p<0.05)$. corn roots are concentrated in the 0-0.20 $\mathrm{m}$ depth (Silva et al., 2000). Furthermore, the quantity and the turnover rate of roots contribute to aggregation (Martins et al., 2009). An increase in aggregation by corn was also reported by other authors for Oxisols from tropical regions of Brazil (Martins et al., 2009; 2012).

Significant differences in soil total porosity were observed only among the winter crops (Table 3). Soil under pigeon pea had higher total porosity compared to soil under corn, oilseed radish, pearl millet, and sunn hemp. The larger quantity of above-ground biomass and residues on the soil surface produced by pigeon pea may have contributed to high total porosity. An increase in the amount of pigeon pea biomass on the soil surface in no-till may enhance total porosity by stimulating the activity of soil microorganisms (Moura et al., 2008).

Neither summer nor winter crops significantly affected micro- and macroporosity (Table 3). Soil under summer crops (e.g., corn/corn and soybean/soybean) and that under winter crops (e.g., corn, oilseed radish, pearl millet, pigeon pea, and sunn hemp) had macroporosity $>0.10 \mathrm{~m} \mathrm{~m}^{-3}$, or above the limit value for adequate root aeration (Dexter, 1988). A higher range of macroporosity has implications for soil erosion, the water infiltration rate during intense rainfalls, and drought. Soil under short-term no-till may have low macroporosity, and this may adversely

Table 2. Water stable aggregates (WSA), mean weight diameter (MWD), geometric mean diameter (GMD), total porosity (TP), microporosity (MI), macroporosity (MA), and soil bulk density (BD) determined at the 0-0.10 $\mathrm{m}$ depth of an Oxisol under summer and winter cropping sequences in a no-till system

\begin{tabular}{|c|c|c|c|c|c|c|c|}
\hline & WSA & MWD & GMD & TP & MI & MA & BD \\
\hline & $\%$ & 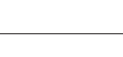 & $\mathrm{n}$ & 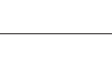 & $\mathrm{m}^{3} \mathrm{~m}^{-3}$ & & $\mathrm{~kg} \mathrm{dm}^{-3}$ \\
\hline \multicolumn{8}{|l|}{ Summer crop (S) } \\
\hline Soybean/corn & 89.66 & $3.55 \mathrm{a}$ & $2.84 \mathrm{a}$ & 0.47 & 0.37 & 0.10 & 1.43 \\
\hline Corn/corn & 90.89 & $3.63 \mathrm{a}$ & $2.92 \mathrm{a}$ & 0.46 & 0.39 & 0.07 & 1.41 \\
\hline Soybean/soybean & 88.75 & $3.18 \mathrm{~b}$ & $2.46 \mathrm{~b}$ & 0.48 & 0.39 & 0.09 & 1.42 \\
\hline $\mathrm{F}$ test & $0.5^{\mathrm{ns}}$ & $13.28^{*}$ & $11.12^{*}$ & $4.47^{\mathrm{ns}}$ & $2.31^{\mathrm{ns}}$ & $2.03^{\mathrm{ns}}$ & $0.36^{\mathrm{ns}}$ \\
\hline CV (\%) & 7.78 & 8.7 & 12.4 & 5.4 & 10.0 & 61.3 & 3.4 \\
\hline \multicolumn{8}{|l|}{ Winter crop (W) } \\
\hline Corn & $89.10 \mathrm{~b}$ & 3.58 & 2.90 & $0.46 \mathrm{~b}$ & 0.39 & 0.08 & 1.44 \\
\hline Sunflower & $87.17 \mathrm{~b}$ & 3.50 & 2.78 & $0.48 \mathrm{ab}$ & 0.39 & 0.10 & 1.42 \\
\hline Oilseed radish & $88.22 \mathrm{~b}$ & 3.43 & 2.57 & $0.46 \mathrm{~b}$ & 0.38 & 0.08 & 1.41 \\
\hline Pearl millet & $89.41 \mathrm{ab}$ & 3.37 & 2.67 & $0.46 \mathrm{~b}$ & 0.38 & 0.08 & 1.41 \\
\hline Pigeon pea & $89.48 \mathrm{ab}$ & 3.17 & 2.44 & $0.50 \mathrm{a}$ & 0.40 & 0.09 & 1.40 \\
\hline Grain sorghum & $91.25 \mathrm{ab}$ & 3.67 & 3.00 & $0.48 \mathrm{ab}$ & 0.38 & 0.10 & 1.43 \\
\hline Sunn hemp & $93.74 \mathrm{a}$ & 3.47 & 2.82 & $0.46 \mathrm{~b}$ & 0.38 & 0.08 & 1.43 \\
\hline $\mathrm{F}$ test & $5.97^{*}$ & $0.67^{\mathrm{ns}}$ & $0.88^{\text {ns }}$ & $7.85^{*}$ & $1.28^{\mathrm{ns}}$ & $1.00^{\mathrm{ns}}$ & $3.52^{\mathrm{ns}}$ \\
\hline CV $(\%)$ & 2.9 & 16.8 & 22.5 & 3.7 & 6.63 & 36.6 & 1.6 \\
\hline \multicolumn{8}{|l|}{ Interaction $\mathrm{S} \times \mathrm{W}$} \\
\hline $\mathrm{F}$ test & $1.26^{\mathrm{ns}}$ & $0.35^{\mathrm{ns}}$ & $0.43^{\text {ns }}$ & $2.30^{\mathrm{ns}}$ & $1.89^{\text {ns }}$ & $4.00^{\mathrm{ns}}$ & $2.72^{*}$ \\
\hline CV (\%) & 4.84 & 17.0 & 22.1 & 5.6 & 6.8 & 30.7 & 2.0 \\
\hline
\end{tabular}

Values followed by the same lowercase letters in the columns are not significantly different by the Tukey test $(\mathrm{p}<0.05) .{ }^{*} \mathrm{p}<0.05$, ns not significant. 
Table 3. Soil bulk density determined in an Oxisol under cropping sequences in no-till

\begin{tabular}{lcccc}
\hline \multirow{2}{*}{ Winter crop } & \multicolumn{3}{c}{ Summer crop } & \\
\cline { 2 - 4 } & Soybean/corn & Corn/corn & Soybean/soybean \\
\cline { 2 - 3 } & & $\mathrm{kg} \mathrm{dm}$ & \\
Corn & $1.45 \mathrm{Aa}$ & $1.40 \mathrm{Ba}$ & $1.43 \mathrm{ABa}$ & \\
Sunflower & $1.40 \mathrm{Aa}$ & $1.41 \mathrm{Aa}$ & $1.45 \mathrm{Aa}$ & $4.93^{*}$ \\
Oilseed radish & $1.40 \mathrm{Aa}$ & $1.42 \mathrm{Aa}$ & $1.40 \mathrm{Aa}$ & $0.58^{\mathrm{ns}}$ \\
Pearl millet & $1.42 \mathrm{Aa}$ & $1.41 \mathrm{Aa}$ & $1.42 \mathrm{Aa}$ & $0.13^{\mathrm{ns}}$ \\
Pigeon pea & $1.44 \mathrm{Aa}$ & $1.37 \mathrm{Aa}$ & $1.39 \mathrm{Aa}$ & $3.17^{\mathrm{ns}}$ \\
Grain sorghun & $1.43 \mathrm{Aa}$ & $1.44 \mathrm{Aa}$ & $1.43 \mathrm{Aa}$ & $0.20^{\mathrm{ns}}$ \\
Sunn hemp & $1.42 \mathrm{Aa}$ & $1.44 \mathrm{Aa}$ & $1.44 \mathrm{Aa}$ & $0.53^{\mathrm{ns}}$ \\
F test & $3.47^{\mathrm{ns}}$ & $2.43^{\mathrm{ns}}$ & $2.18^{\mathrm{ns}}$ & \\
\hline
\end{tabular}

Values followed by the same letter, lowercase letters in the columns and uppercase letters in the lines, are not significantly different by the Tukey test $(\mathrm{p}<0.05) .{ }^{*} \mathrm{p}<0.05,{ }^{\text {ns }}$ not significant.

affect plant growth (Bertol et al., 2004). However, macroporosity is not restrictive in soil under longterm no-till farming (Da Silva et al., 2012) because of the formation of biopores and alleviation of soil compaction (Schäffer et al., 2008), and enhanced connectivity of pores, which is more important for functionality than total porosity and macroporosity (Cavalieri et al., 2009).

Analysis of variance showed a significant effect of interaction (summer $\times$ winter crops) on bulk density (BD) (Table 3). Soil under corn as a winter crop had higher BD for soybean/corn compared to corn/corn among summer crops. A reduction in BD in soil under corn/corn (as summer and winter crops) may be caused by an increase in SOC content and mean weight diameter. An increase in SOC content decreases BD and soil resistance to penetration, and enhances pore size distribution and available water content (Kumar et al., 2012). Furthermore, corn roots may reduce BD by the formation of biopores in the soil profile (Dexter, 1991).

The least limiting water range (LLWR) was not at maximum potential for all crop sequences since available water content was higher than the LLWR (Figures 3, 4, and 5). The maximum value of the LLWR is equal to the available water content, where only soil water potential limits plant growth (Silva et al., 1994). Regardless of BD under all crop sequences, water content at the soil resistance to penetration of 3.5 MPa was the lower limit of the LLWR, and was higher than the permanent wilting point (Figures 3 , 4 , and 5). These trends may be attributed to absence of soil disturbance under no-till, which can influence the available water content of the soil (Carter et al., 1999). Soil resistance to penetration as the lower limit of the LLWR was also confirmed by Tormena et al. (2007) and Calonego \& Rosolem (2011). Furthermore, high values of soil resistance to penetration in the Oxisol under study may be attributed to the kaolinitic mineralogy of the clay fraction. Kaolinitic Oxisols have higher BD than gibbsitic Oxisols because of the block structure and face-to-face configuration adjustment of the kaolinite plates (Ferreira et al., 1999). The horizontal arrangement of clay particles makes soil susceptible to compaction, especially under no-till and the absence of mechanical disturbance.

The LLWR was higher in soil under the summer cropping sequence of soybean/corn followed by corn and pigeon pea as winter crops (Figure 3). An increase in the LLWR was influenced by a decrease in soil resistance to penetration with an increase in BD. Such trends may be attributed to the presence of retention pores in the soil. Furthermore, the effects of an increase in water retention on reduction in soil resistance to penetration may be attributed to a decrease in soil strength through a lubricant effect among mineral particles (Tormena et al., 2007; Blainski et al., 2012). Calonego \& Rosolem (2011) also observed that a notill crop rotation with triticale and pearl millet enhanced the formation of biopores in the soil by reduction of soil resistance to penetration to values similar to those observed after chiseling. However, soil resistance to penetration under most cropping sequences increased with an increase in $\mathrm{BD}$, probably because of the increase in the cohesive forces among mineral particles (Tormena et al., 2007; Blainski et al., 2012). Similar results have been reported by others (Silva et al., 1994; Tormena et al., 1998; Leão \& Silva, 2004; Tormena et al., 2007).

The largest and the smallest values of the LLWR were observed under sunflower as a winter crop when grown within the corn/corn and soybean/soybean sequences as summer crops (Figures $4 \mathrm{~b}$ and $5 \mathrm{~b}$ ). A small value of the LLWR indicates degradation of soil structure and the need for sustainable management. Thus, the LLWR is an index of soil quality in relation to plant growth (Letey, 1985).

The upper limit of the LLWR in soil under all crop sequences was initially represented by the moisture field capacity. Field capacity as the upper limit of the 


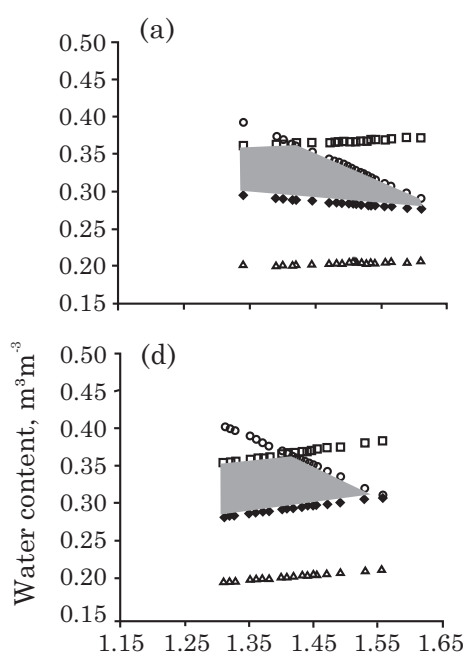

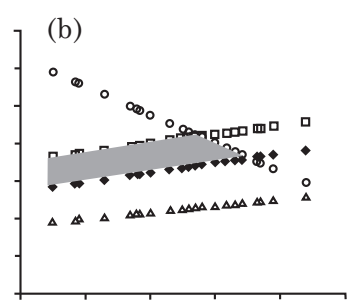
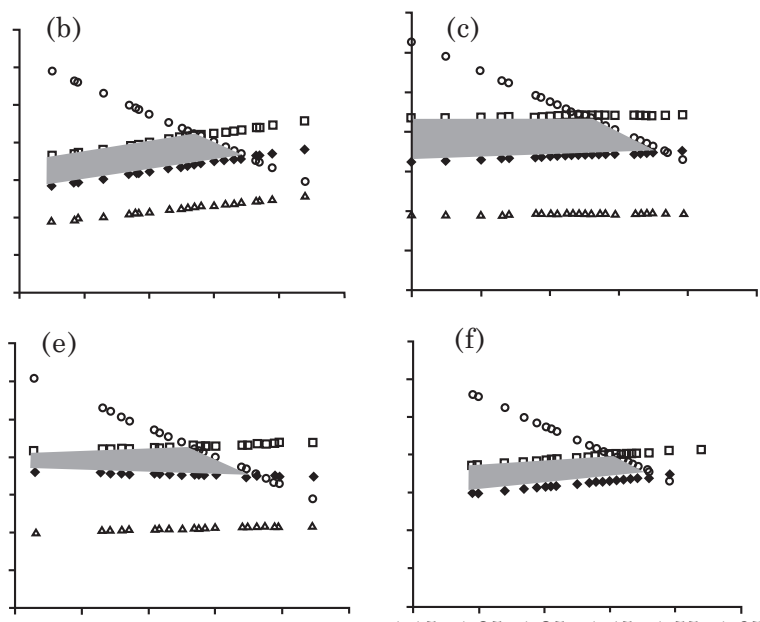

(f)
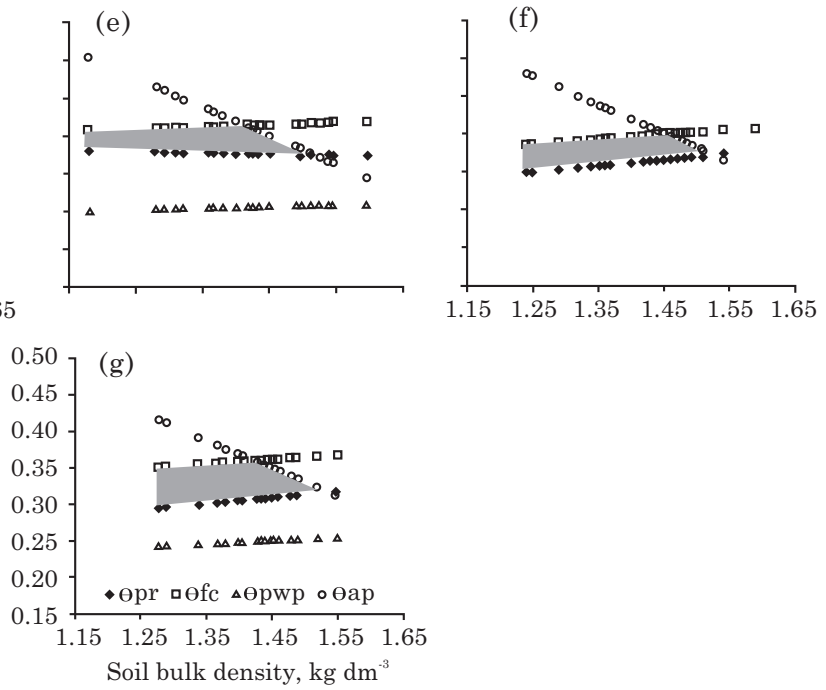

Figure 3. Least limiting water range in soil under winter crops [(a) corn, (b) sunflower, (c) oilseed radish, (d) pearl millet, (e) pigeon pea, (f) grain sorghum, and (g) sunn hemp] within soybean/corn in summer in which $o=$ air-filled porosity, $\square=$ field capacity, $\diamond=$ soil resistance to penetration, and $\Delta=$ permanent wilting point.
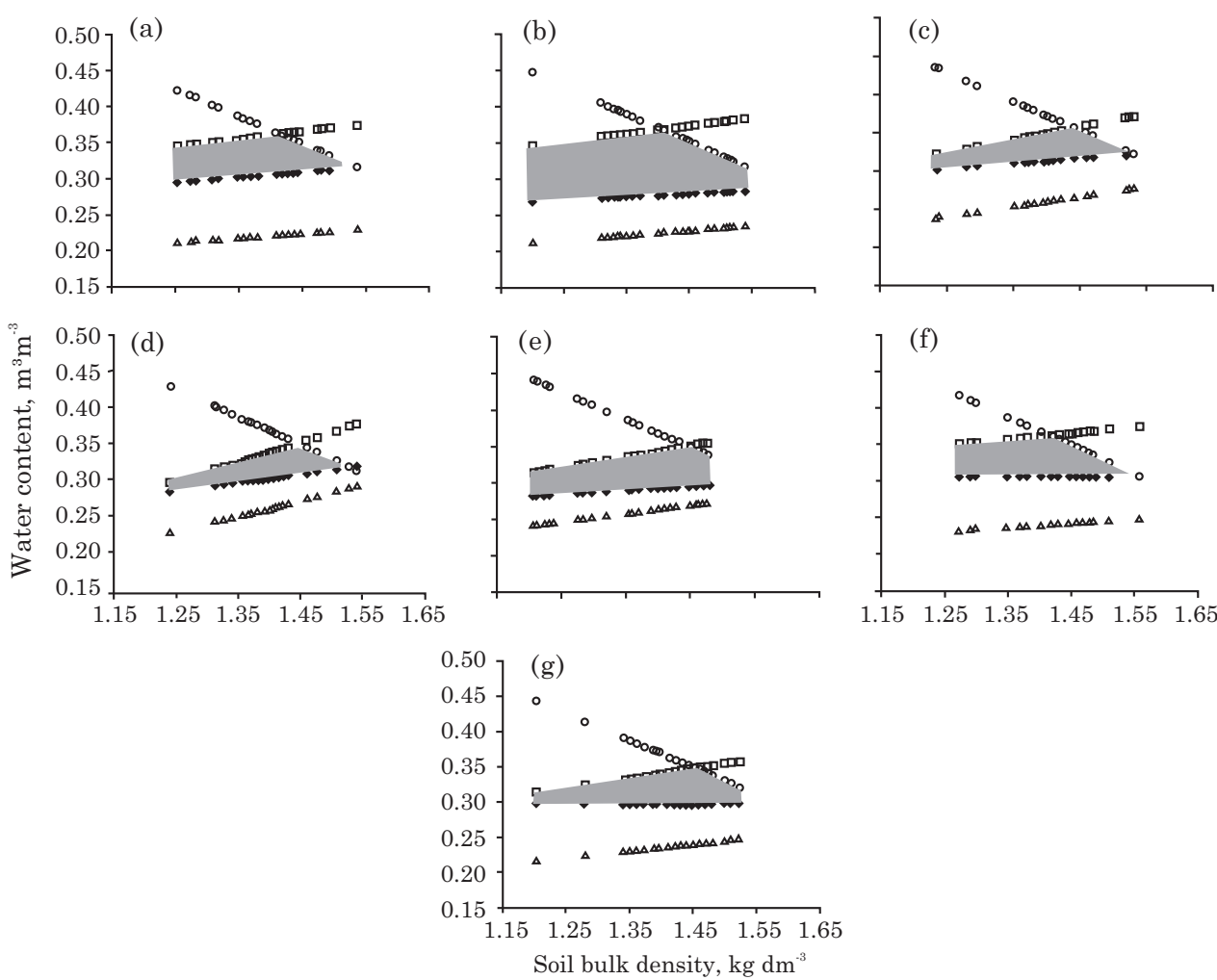

Figure 4. Least limiting water range in soil under winter crops [(a) corn, (b) sunflower, (c) oilseed radish, (d) pearl millet, (e) pigeon pea, (f) grain sorghum, and (g) sunn hemp] within corn/corn in summer in which o= air-filled porosity, $\square=$ field capacity, $\diamond=$ soil resistance to penetration, and $\Delta=$ permanent wilting point. 

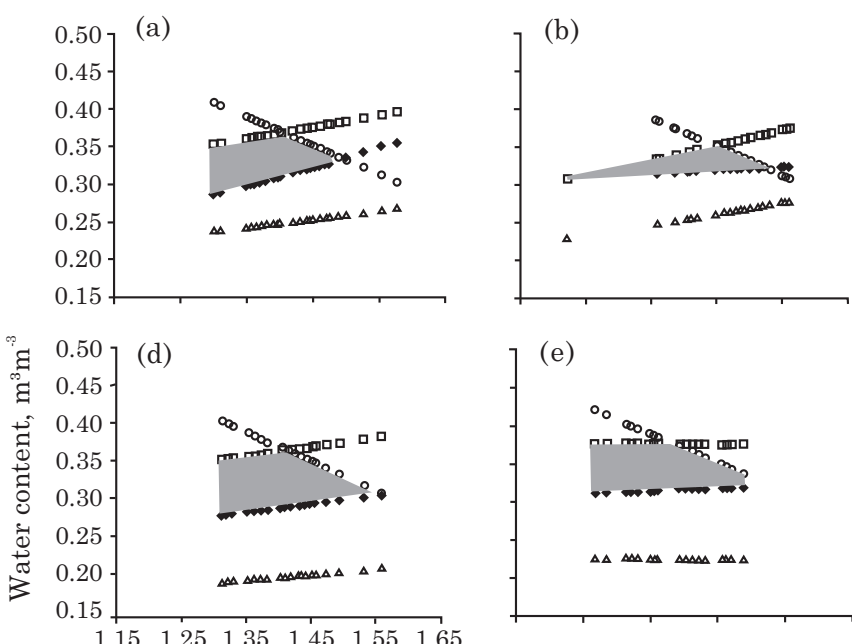

(e)
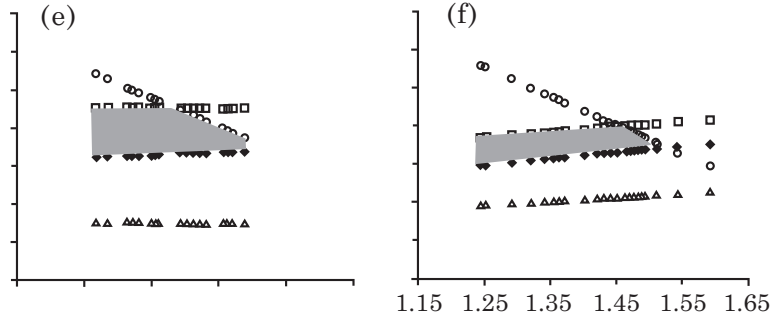

(g)

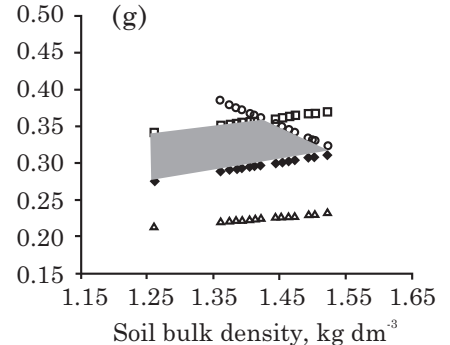

Figure 5. Least limiting water range under winter crops [(a) corn, (b) sunflower, (c) oilseed radish, (d) pearl millet, (e) pigeon pea, (f) grain sorghum, and (g) sunn hemp] within soybean/soybean in summer in which $o=$ air-filled porosity, $\square=$ field capacity, $\diamond=$ soil resistance to penetration, and $\Delta=$ air-filled porosity.

LLWR suggests that cropping sequences are increasing soil water content and maintaining a minimum value of the air-filled porosity necessary for adequate root aeration. Thus, for the upper limit for the 1 LLWR, field capacity was replaced by airfilled porosity at the different values of $\mathrm{BD}$ observed under each cropping sequence. An earlier replacement occurred in soil under soybean/corn in summer and oilseed radish in winter and soybean/soybean in summer and pearl millet in winter with a BD of $1.39 \mathrm{~kg} \mathrm{dm}^{-3}$ (Figures $3 \mathrm{c}$ and $5 \mathrm{~d}$ ). Similarly, a late replacement occurred under corn/corn in summer with pigeon pea in winter with a BD of $1.46 \mathrm{~kg} \mathrm{dm}^{-3}$ (Figure 4e). Early replacement may be attributed to reduction in macropores by an increase in BD and increasing soil water retention but decreasing air-filled porosity. Air-filled porosity becomes restrictive under no-till in those cropping sequences which decrease macroporosity, mainly biopores, which promotes water infiltration (Tormena et al., 2007). However, late replacement may mean that cropping sequences are increasing stable and continuous biopores and improving aeration (Tormena et al., 2007).

The average BD under all cropping sequences was lower than the critical BD obtained in the LLWR (Figures 3, 4, and 5). However, soil under some cropping sequences had $\mathrm{BD}$ values higher than the critical BD. These cropping sequences included: soybean/corn as summer crops followed by winter crops of sunflower (14.3\%), pigeon pea (17.9\%), grain sorghum $(7.1 \%)$, and sunn hemp (3.6\%); corn/corn followed by the winter crop of pearl millet (7.1\%); and soybean/soybean followed by winter crops of corn (14.3\%), sunflower (10.7\%), oilseed radish (10.7\%), pearl millet (3.6\%), and grain sorghum (3.6\%). Critical BD was associated with low water content in soil under winter crops within each summer cropping sequence. These cropping sequences may be prone to restricted crop growth and development. In the present study, the critical $B D$ values were higher than the value of $1.30 \mathrm{~kg} \mathrm{dm}^{-3}$ reported by Tormena et al. (2007) in an Oxisol under no-till for the crop succession of soybean-wheat (18\%), crop rotation corn-wheat soybean-oat-soybean-oat (18\%), and crop rotation plus chiseling (5\%), with the same critical value of soil resistance to penetration (3.5 $\mathrm{MPa})$.

Bulk density was positively correlated with water content. An increase in BD and, consequently, water content decreases air-filled porosity, which can restrict root growth (Tormena et al., 2007). Normal stress by wheel traffic can reduce soil volume, decrease pore diameter, and reduce water retention at high matric potentials (Silva et al., 1994; Tormena et al., 1998). An increase in water retention is important to become available water content for plant growth during the 
dry season. But a decline in air-filled porosity may reduce air porosity during seasons of intense rainfall. Both conditions are common in soils of tropical regions.

\section{CONCLUSIONS}

1. Cropping sequences strongly influence soil structure; soil under soybean/corn and corn/corn have higher mean weight diameter and geometric mean diameter than under soybean/soybean.

2. Soil under sunn hemp and grain sorghum as winter crops has higher soil organic carbon content compared to soil under sunflower.

3. Cultivation of pigeon pea increases soil total porosity.

4. Soil resistance to penetration decreases with an increase in bulk density in soil under soybean/corn followed by corn and pigeon pea as winter crops because of the creation of biopores.

5 . The largest and smallest values of the least limiting water range are observed in soil planted to sunflower within the corn/corn sequence and planted to sunflower within the soybean/soybean sequence.

\section{ACKNOWLEDGMENTS}

We are grateful to the CAPES Foundation of the Ministry of Education of Brazil for financial support for this study (Process 8745/11-0). Thanks also to the Universidade Estadual Paulista and The Ohio State University for the doctoral exchange program for the first author.

\section{LITERATURE CITED}

ALVARENGA, R.C.; COSTA, L.M.; MOURA FILHO, W. \& REGAZZI, A.J. Características de alguns adubos verdes de interesse para a conservação e recuperação de solos. Pesq. Agropec. Bras., 30:175-185, 1995.

AMADO, T.J.C.; BAYER, C.; ELTZ, F.L.F. \& BRUM, A.C.R. Potencial de culturas de cobertura em acumular carbono e nitrogênio no solo no plantio direto e a melhoria da qualidade ambiental. R. Bras. Ci. Solo, 25:189-197, 2001.

BAYER, C.; MARTIN-NETO, L.; MIELNICZUK, J.; PAVINATO, A. \& DIECKOW, J. Carbon sequestration in two Brazilian Cerrado soils under no-till. Soil Till. Res., 86:237-245, 2006.

BAYER, C.; MIELNICZUK, J.; AMADO, T.J.C.; MARTIN-NETO, L. \& FERNANDES, S.A. Organic matter storage in a sandy loam Acrisol affected by tillage and cropping systems in southern Brazil. Soil Till. Res., 54:101-109, 2000.
BERTOL, I.; ALBUQUERQUE, J.A.; LEITE, D.; AMARAL, A.J. \& ZOLDAN JUNIOR, W.A. Propriedades físicas do solo sob preparo convencional e semeadura direta em rotação e sucessão de culturas comparadas às do campo nativo. R. Bras. Ci. Solo, 28:155-163, 2004.

BEUTLER, A.N.; SILVA, M.L.N.; CURI, N.; FERREIRA, M.M.; PEREIRA FILHO, I.A. \& CRUZ, J.C. Agregação de Latossolo Vermelho distrófico típico relacionada com o manejo na região dos cerrados no Estado de Minas Gerais. R. Bras. Ci. Solo, 25:129-136, 2001.

BLAINSKI, E.; TORMENA, C.; GUIMARÃES, R.M.L. \& NANNI, M.R. Qualidade física de um Latossolo sob plantio direto influenciada pela cobertura do solo. R. Bras. Ci. Solo, 36:79-87, 2012.

CALONEGO, J.C. \& ROSOLEM, C.A. Least limiting water range in soil under crop rotations and chiseling. R. Bras. Ci. Solo., 35:759-771, 2011.

CALONEGO, J.C. \& ROSOLEM, C.A. Soybean root growth and yield in rotation with cover crops under chiseling and no-till. Eur. J. Agron., 33:242-249, 2010.

CARTER, M.R.; ANGERS, D.A. \& TOPP, G.C. Characterizing equilibrium physical condition near the surface of a fine sandy loam under conservation tillage in a humid climate. Soil Sci., 164:101-110, 1999.

CARVALHO, A.M.; BUSTAMANTE, M.M.C.; ALCÂNTARA, F.A.; RESCK, I.S. \& LEMOS, S.S. Characterization by solid-state CPMAS ${ }^{13} \mathrm{C}$ NMR spectroscopy of decomposing plant residues in conventional and no-tillage systems in Central Brazil. Soil Till. Res., 102:144-150, 2009.

CAVALIERI, K.M.V.; SILVA, A.P.; TORMENA, C.A.; LEÃO, T.P.; DEXTER, A.R. \& HÅKANSSON, I. Long-term effects of no-tillage on dynamic soil structure properties in a Rhodic Ferrasol in Paraná, Brazil. Soil Till. Res., 103:158-164, 2009.

DANE, J.H. \& HOPMANS, J.W. Pressure plate extractor. In: DANE, J.H. \& TOPP, C., eds. Methods of soil analysis: Structure methods. Madison, Soil Science Society of America, 2002. p.688-690.

DA SILVA, V.L.; DIECKOW, J.; MELLEK, J.E.; MOLIN, R.; FAVARETTO, N.; PAULETTI, V. \& VEZZANI, F.M. Melhoria da estrutura de um Latossolo por sistemas de culturas em plantio direto nos Campos Gerais do Paraná. . R. Bras. Ci. Solo., 36:983-992, 2012.

DEXTER, A.R. Advances in characterization of soil structure. Soil Till. Res., 11:199-238, 1988.

DEXTER, A.R. Amelioration of soil by natural processes. Soil Till. Res., 20:87-100, 1991.

EHLERS, W.; KÖPKE, U.; HESSE, F. \& BÖHM, W. Penetration resistance and root growth of oats in tilled and untilled loess soil. Soil Till. Res., 3:261-275, 1983.

ELLERT, B.H. \& BETTANY, J.R. Calculation of organic matter and nutrients stored in soils under contrasting management regimes. Can. J. Soil Sci., 75:529-538, 1995.

ELTZ, F.L.F. \& ROVEDDER, A.P.M. Revegetação e temperatura do solo em áreas degradadas no sudoeste do Rio Grande do Sul. R. Bras. Agroci., 11:193-200, 2005. 
FERREIRA, M.M.; FERNANDES, B. \& CURI, N. Mineralogia da fração argila e estrutura de Latossolos da região sudeste do Brasil. R. Bras. Ci. Solo, 23:507-514, 1999.

FIGUEIREDO, G.C.; SILVA, A.P.; TORMENA, C.A.; GIAROLA, N.F.B.; OLIVEIRA, S.O. \& ALMEIDA, B.G. Improvement of a testing apparatus for dynamometry: procedures for penetrometry and influence of strain rate to quantify the tensile strength of soil aggregates. R. Bras. Ci. Solo, 35:373-387, 2011.

FLINT, L.E. \& FLINT, A.L. Porosity. In: DANE, J.H. \& TOPP, G.C., eds. Methods of soil analysis: Physical methods. Madison, Soil Science Society of America, 2002. p.241253.

GEE, G.W. \& BAUDER, J.W. Particle size analysis. In: KLUTE, A., ed. Methods of soil analysis. 2.ed. Madison, America Society of America/Soil Science Society of America, 1986. p.383-411.

GRABLE, A.R. \& SIEMER, E.G. Effects of bulk density, aggregate size, and soil water suction on oxygen diffusion, redox potential and elongation of corn roots. Soil Sci. Soc. Am. J., 32:180-186, 1968.

HUNGRIA, M.; CAMPO, R.J. \& MENDES, I.C. Fixação biológica do nitrogênio na cultura da soja. Brasília, Embrapa Cerrados, 2001.

KEMPER, W.D. \& ROSENAU, R.C. Aggregate stability and size distribution. In: KLUTE, A., ed. Methods of soil analysis: Structure and mineralogical methods. Madison, America Society of America/Soil Science Society of America, 1986. p.635-660.

KUMAR, S.; KADONU, A.; LAL, R. \& DICK, W. Long-term no-till impacts on organic carbon and properties of two contrasting soils and corn yields in Ohio. Soil Sci. Soc. Am. J., 76:1798-1809, 2012.

LEÃO, T.P. \& SILVA, A.P. A simplified excel algorithm for estimating the least limiting water range of soils. Sci. Agric., 61:649-654, 2004.

LETEY, J. Relationship between soil physical properties and crop production. Adv. Soil Sci., 1:277-294, 1985.

MARCELO, A.V.; CORÁ, J.E. \& FERNANDES, C. Sequências de culturas em sistema de semeadura direta. I - Produção de matéria seca e acúmulo de nutrientes. R. Bras. Ci. Solo, 36:1553-1567, 2012.

MARCELO, A.V.; CORA, J.E.; FERNANDES, C.; MARTINS, M.R. \& JORGE, R.F. Cropping sequences in no-tillage system: Effects on soil fertility and soybean, maize and rice production. R. Bras. Ci. Solo, 33:417-428, 2009.

MARTINS, M.R.; ANGERS, D.A. \& CORA, J.E. Carbohydrate composition and water-stable aggregation of an Oxisol as affected by crop sequence under no-till. Soil Biol. Biochem., 76:475-484, 2012.

MARTINS, M.R.; CORÁ, J.E.; JORGE, R.F. \& MARCELO, A.V. Crop type influences soil aggregation and organic matter under no-tillage. Soil Till. Res., 104:22-29, 2009.

MOURA, E.G.; ALBUQUERQUE, J.M. \& AGUIAR, A.C.F. Growth and productivity of corn as affected by mulching and tillage in alley cropping systems. Sci. Agric., 65:204$208,2008$.
NELSON, D.W. \& SOMMERS, L.E. Total carbon, organic carbon, and organic matter. In: PAGE, A.L.; MILLER, R.H. \& KEENEY, D.R., eds. Methods of soil analysis: Chemical and microbiological properties. Madison, America Society of America/Soil Science Society of America, 1982. p.539-579.

NIMMO, J.R. \& PERKINS, K.S. Aggregate stability and size distribution. In: DANE, J.H. \& TOPP, G.C., eds. Methods of soil analysis. Madison, America Society of America/ Soil Science Society of America, 2002. p.317-327.

PACHECO, L.P.; LEANDRO, W.M.; MACHADO, P.L.O.A.; ASSIS, R.L.; COBUCCI, T.; MADARI, B.E. \& PETTER, F.A. Produção de fitomassa e acúmulo e liberação de nutrientes por plantas de cobertura na safrinha. Pesq. Agropec. Bras., 46:17-25, 2011.

REICHARDT, K. Capacidade de campo. R. Bras. Ci. Solo, 12:211-216, 1988.

REICHERT, J.M.; SUZUKI, L.E.A.S.; REINERT, D.J.; HORN, R. \& HÅKANSSON, I. Reference bulk density and critical degree-of-compactness for no-till crop production in subtropical highly weathered soils. Soil Till. Res., 102:242$254,2009$.

REYNOLDS, W.D.; BOWMAN, B.T.; DRURY, C.F.; TAN, C.S. \& LU, X. Indicators of good soil physical quality: density and storage parameters. Geoderma, 110:131-146, 2002.

ROMANO, N.; HOPMANS, J.W. \& DANE, J.H. Suction table. In: DANE, J.H. \& TOPP, C., eds. Methods of soil analysis: Structure methods. Madison, America Society of America/ Soil Science Society of America, 2002. p.692-698.

SANTOS, N.Z.; DIECKOW, J.; BAYER, C.; MOLIN, R.; FAVARETTO, N.; PAULETTI, V. \& PIVA, J.T. Forages, cover crops and related shoot and root additions in no-till rotations to $\mathrm{C}$ sequestration in a subtropical Ferralsol. Soil Till. Res., 111:208-218, 2011.

SAVAGE, M.J.; RITCHIE, J.T.; BLAND, W.L. \& DUGAS, W.A. Lower limit of soil water availability. Agron. J. 88:644$651,1996$.

SCHÄFFER, B.; STAUBER, M.; MUELLER, T.L.; MÜLLER, R. \& SCHULIN, R. Soil and macropores under uniaxial compression. Mechanical stability of repacked soil and deformation of different types of macropores. Geoderma, 146:183-191, 2008.

SILVA, A.P.; KAY, B.D. \& PERFECT, E. Characterization of the least limiting water range. Soil Sci. Soc. Am. J., 58:1775-1781, 1994.

SILVA, E.C.; MURAOKA, T.; VILLANUEVA, F.C.A. \& ESPINA, F.S.C. Aproveitamento de nitrogênio pelo milho, em razão da adubação verde, nitrogenada e fosfatada. Pesq. Agropec. Bras., 44:118-127, 2009.

SILVA, I.F. \& MIELNICZUK, J. Ação do sistema radicular de plantas na formação e estabilização de agregados do solo. R. Bras. Ci. Solo, 21:113-117, 1997.

SILVA, V.R.; REINERT, D.J. \& REICHERT, J.M. Densidade do solo, atributos químicos e sistema radicular do milho afetados pelo pastejo e manejo do solo. R. Bras. Ci. Solo, 24:191-199, 2000. 
SIX, J.; FELLER, C.; DENEF, K.; OGLE, S.M.; SÁ, J.C.M. \& ALBRECHT, A. Soil organic matter, biota and aggregation in temperate and tropical soils - Effects of no-tillage. Agronomie, 22:755-775, 2002.

SOIL SURVEY STAFF - SSS NRCS. Keys to soil taxonomy. 11.ed. Washington, USDA, 2010. 338p.

SOLLINS, P.; HOMMAN, P. \& CALDWELL, B.A. Stabilization and destabilization of soil organic matter: Mechanisms and controls. Geoderma, 74:65-105, 1996.

STOTT, D.E.; STROO, H.F.; ELLIOTT, L.F.; PAPENDICK, R.I. \& UNGER, P.W. Wheat residue loss from fields under no-till management. Soil Sci. Soc. Am. J., 54:92-98, 1990.

TOPP, G.C.; REYNOLDS, W.D.; COOK, F.J.; KIRBY, J.M. \& CARTER, M.R. Physical attributes of soil quality. In: GREGORICH, E.G. \& CARTER, M.R., eds. Soil quality for crop production and ecosystem health. New York, Elsevier, 1997. p.21-58.
TORMENA C.A.; ARAÚJO, M.A.; FIDALSKI, J. \& COSTA, J.M. Variação temporal do intervalo hídrico ótimo de um Latossolo Vermelho distroférrico sob sistemas de plantio direto. R. Bras. Ci. Solo, 31:211-219, 2007.

TORMENA C.A.; SILVA, A.P. \& LIBARDI, P.L. Caracterização do intervalo hídrico ótimo de um Latossolo Roxo sob plantio direto. R. Bras. Ci. Solo, 22:573-581, 1998.

WEST T.O. \& POST, W.M. Soil organic carbon sequestration rates by tillage and crop rotation: a global data analysis. Soil Sci. Soc. Am. J., 66:1930-1946, 2002.

WILLIAMS, S.M. \& WEIL, R.R. Crop cover root channels may alleviate soil compaction effects on soybean crop. Soil Sci. Soc. Am. J., 68:1403-1409, 2004.

YODER, R.E. A direct method of aggregate analysis of soils and a study of the physical nature of erosion losses. Agron. J., 28:337-351, 1936. 